\title{
Implementation of Word Monopoly as a Learning Media to Improve Creative and Moral Attitudes in the Students of Class IV Students in Grade IV of SDN Srengseng Sawah 15 Pagi
}

\author{
Efi Syalfifi", Mohamad Syarif Sumantri, Durotul Yatima, Adi Apriadi Adiansha \\ Department of Primary Education, State University of Jakarta, Jakarta, Indonesia \\ *Corresponding author: syalfifitanjung@yahoo.co.id
}

Received December 03, 2018; Revised January 09, 2019; Accepted January 23, 2019

\begin{abstract}
This study aims to apply the word monopoly as a learning medium to improve creative thinking and moral attitudes in the content of the PPKN class IV Srengseng Sawah 15 Pagi. This study uses the method of action research model Kemmis and Taggart, which includes four stages, namely (1) planning, (2) action, (3) observation, (4) reflection. The results showed that the use of the word monopoly media was able to improve the ability to think creatively in the fourth grade students of SDN Srengseng Sawah 15 Pagi, especially on the theme of the beauty of togetherness; By carrying out the word monopoly game which includes images and question questions related to the material beauty of togetherness, students are grouped 5-6 students in each group to answer each question in the monopoly of the words printed on each of the general and special funding questions and students present the accelerator by giving ideas, ideas or solutions, honesty, confidence, and courage to solve questions that are in the game; The advantage of word monopoly media is being able to improve the ability to think creatively, able to increase student activeness, speaking skills when expressing their opinions, communicating diverse answers, being able to issue ideas or solutions in solving problems.
\end{abstract}

Keywords: creative thinking, moral attitude, word monopoly

Cite This Article: Efi Syalfifi, Mohamad Syarif Sumantri, Durotul Yatima, and Adi Apriadi Adiansha, "Implementation of Word Monopoly as a Learning Media to Improve Creative and Moral Attitudes in the Students of Class IV Students in Grade IV of SDN Srengseng Sawah 15 Pagi.” American Journal of Educational Research, vol. 7, no. 1 (2019): 97-103. doi: 10.12691/education-7-1-15.

\section{Introduction}

Curriculum 2013 has a special purpose to prepare a new generation and successor of the nation that has the ability to live as individuals and citizens who are faithful, productive, creative, innovative, and effective and able to contribute to the life of the world, nation, state, and civilization [1]. For this reason, the 2013 Curriculum design pays attention to the needs of students today and in the future in the midst of the influence of globalization and the plurality of Indonesian society and to strengthen the character of students which includes the five main values of religion, nationalism, independence, mutual cooperation and integrity.

In connection with the above, Kim's research in the journal Perry and Karpova suggests that, for the first time in decades, creativity has declined in the United States in all age groups. The decline in creativity is evident in the children being less imaginative, expressive verbal, enthusiastic, able to synthesize various information, motivated to elaborate various ideas and details, able to capture the essence of the problem, intellectually curious, and open to new experiences. The potential consequences of this tendency are very far away because creativity is very important in every aspect of our lives [2].

So from that 2013 Curriculum Competencies developed on instruments to direct students to become: 1) quality human beings who are able and proactive to respond to the challenges of an ever-changing era; 2) educated people who believe and fear God Almighty, have noble character, are healthy, knowledgeable, capable, creative, independent; and 3) democratic citizens, responsible [1]. As a teacher provides provisions by facilitating students in the learning process not only knowledge that increases along with the moral attitudes of students.

The learning of Pancasila and Citizenship Education is a subject that generally aims to develop the individual potential of Indonesian citizens, so that they have adequate citizenship insight, attitudes and skills and enable them to participate intelligently and responsibly in various social, national and national lives. state. According to Suwanto, subjects are one of the subjects which include lessons in understanding, living and practicing them in everyday life [3]. Planting the right concept at the elementary school 
level is the provision of students to learn to apply it in everyday life from the very beginning.

Based on a study of the Pancasila and Citizenship Education curriculum policy conducted by the Ministry of National Education in 2008 showed that most teachers of Pancasila and Citizenship Education were less than optimal in using innovative learning models, whereas in the learning process there was also an active involvement of students in developing critical thinking. and creative thinking.

Competence in creative thinking for students is very important in the era of globalization. Creative thinking is classified as high order competencies and can be seen as a continuation of basic competencies in line with Ervyne's statement that creativity plays an important role in the cycle of advanced mathematical thinking. According to the Maine Carreer Center Department of Labor, the ability to think creatively is also a determinant of the superiority of a nation [4]. The competitive power of a nation is largely determined by the creativity of its human resources.

Based on the results of the learning observation in class IV, it shows that there are obstacles encountered in the learning of Pancasila and Citizenship Education, namely: 1) Students tend not to be so interested because so far PPKn lessons are considered as lessons that are only concerned with memorization; 2) Students tend to feel bored because in the implementation of learning the teacher is less than optimal using innovative learning; 3) Students are not given the opportunity to search, ask, answer and issue opinions so that they have a negative impact on the ability to think creatively in the learning process. This results in no interaction between students and teachers, where a teacher does not provide space for students to explore the ideas of Pancasila and Citizenship Education with creative thinking skills and moral attitudes of students.

Data on the average learning outcomes of fourth grade students on Pancasila and Citizenship Education subjects on theme 1 are My Cultural Diversity with Minimum Completion Criteria the content of Pancasila and Citizenship Education lessons in class IV is 65 education of SDN srengseng Sawah 15 is 63). Of the total 32 students, only 6 students (21\%) reached the Minimum Completion Criteria while 26 students (79\%) did not reach the Minimum Completion Criteria. Student learning outcomes data can be concluded that the learning outcomes of class IV students in learning Pancasila and Citizenship Education are categorized still low.

Regarding the ability of students to think creatively which is still low, it can be seen in the learning process on 15 September 2018 in the content of Pancasila and Citizenship Education lessons where when the teacher asks questions that stimulate students to think creatively, on average students are mentally weak to answer individually. In the opinion of Miller \& Dumford in Creative thinking is an essential soft skill for future and impacts on the development of innovation. Creative thinking is soft skills that are important for the future and have an impact on the development of innovation [5].

On the other hand moral values in the form of selfconfidence and courtesy in answering based on observations are still weak. Students tend to be afraid of being wrong and afraid of being humiliated by other friends. Mentally they are also weak to be seen from them rarely issued an opinion if they answered together. When answering individually students tend to give short and standard answers and are not fluent in giving their ideas and opinions. No one asks questions about the material from the beginning to the end of the lesson. The attitude of modesty is also still less visible when there are students who answer other students cheering and laughing so that the students who answer it seem embarrassed and angry and even hit their friends who laugh at them. When given the task of the teacher the value of discipline and perseverance in working on the task is still weak, lazy to complete the task and not discipline in the completion of the task. The social value of students is also still weak, this can be seen from the rare students working on tasks together.

Regarding the response above Andreev in the Yachina journal the problem students expressed; The concept of "conscience" with a feeling of shame. The word conscience ("co" - "manage") means that the inner voice tells us that we are doing something wrong and is the wrong way. Conscience acts as a spiritual mechanism, we have accepted. We need to develop a conscience in different situations by means of education [6].

The concept of "conscience" with shame. The word conscience ("co" - "managing") means that the inner voice tells us that we are doing something wrong and in the wrong way. Conscience acts as a spiritual mechanism, improving our behavior in terms of moral and ethical standards, we have accepted. We need to develop a conscience in different situations through education.

Reinforced by Kohlberg's opinion in the journal Bužgová and Sikorová stated; The moral judgment of competence is the ability to make a moral judgment and act according to these judgments. An individual's degree of moral development is determined by the level of internalization of social norms and values and the level of dependence on the external control of behavior [7].

Moral assessment competencies are the ability to make moral judgments and act according to this judgment. A person's degree of moral development is determined by the level of internalization of norms and social values and the degree of dependence on external behavior control.

Based on the description of the problem above, the learning must be improved by the teacher, one of them is by applying the game media. Media games are chosen as learning media because in the game students are involved in the process of experience and at the same time live the challenges to get inspiration, are encouraged to be creative and interact directly with fellow students who are members of the game. Where in the game there is an activity of exchanging experiences and opinions that lead to debate and arguing with each other. This can develop a more meaningful learning process and learning process.

The success of the learning process is inseparable from the ability of the teacher to develop learning models that are oriented towards increasing the intensity of student involvement effectively in the learning process. To be able to develop an effective learning model, each teacher must have adequate knowledge regarding the concepts and ways to implement these models in the learning process. A teacher's lack of understanding of these conditions causes the model developed by the teacher tends to not be 
able to optimally improve the student's role in learning, and in the end cannot contribute significantly to the achievement of student learning outcomes.

Therefore, a teacher is required to know how creative students are in solving a problem and in the learning process the teacher must use a learning strategy or model. One of the media games that can facilitate student activities in meaningful learning experiences is the word monopoly game [8]. Monopoly media can be an alternative to overcome the above problems. Monopoly media is able to bring students to play a direct role in the game scheme which can trigger their activeness in their learning situation.

Samrin's opinion was strengthened about three components of good character, namely knowledge about morals (moral knowing), feelings about moral (moral feeling), and moral actions. Another feature of this monopoly media is that this media is played by four participants so that in this game there will be social interactions which indirectly also train students' skills in interacting with others [9].

The word monopoly game is one of the games. If they exchange experiences, defend their opinions, then a great debate may arise. But they learn wisely to combine or form conclusions that are closer to the truth. Behavior in the game, the inner processes that are felt by each and expressions in the form of words and behavior will be the material of observation of the perpetrators and to understand the process of developing their potential, or raise awareness of the truth or the whole as a quality personality formation material.

According to Schoen and Jessup in O'Halloran and Deale's journals, the adaptations of monopoly for educational purposes include politics, a game for psychology courses, and sociology, a game that is set up like a regular Monopoly game, but teams have different resources at the beginning of the game, providing students with insights into social inequalities. Variations of Monopoly are abundant and some are notable examples follow [10].

Monopoly adaptation for goal education includes Monopoly, a game for psychology and Sociology courses, a game that is regulated as usual Monopoly games, but teams have different resources at the beginning of the game, providing students with an insight into social inequality. Monopoly variations abound and several important examples to follow.

So, games are facts that are analyzed to understand the process of behavior in the game; the choice of each decision in acting or saying becomes a conclusion as selfproducing learning. Media games are seen as important because at the age of elementary school fourth-grade monopoly which is one of the media games that can lead to interesting learning activities and help the learning atmosphere to be happy, lively and relaxed.

According to Fitriyawani, the results of research by experts who have tested the feasibility of monopoly game media provide the conclusion that the game of monopoly is suitable to be used as a learning medium because this monopoly game media is one of the media games that can lead to interesting, lively, fun and relaxed teaching and learning activities. have the ability to engage students in teaching and learning activities actively in solving existing problems [11].
Therefore, learning Citizenship Education through the medium of monopoly refers to the characteristics of elementary school students who like to play. According to Anggani Sudono, Playing is an activity carried out with or without using tools that produce understanding or provide information, give pleasure and develop imagination in children [12]. Playing is very important for the physical, psychological and social development of elementary school students so that the process of the ability to think creatively through the media of monopoly games will be fun and will make students interested in learning Pancasila and Citizenship Education.

Based on the explanation above, the researcher tried "The Application of Word Monopoly as a Learning Media to Improve Creative Thinking and Moral Attitudes on the Content of Pancasila and Citizenship Education Lessons in Class IV Srengseng Sawah 15 Pagi Elementary School". This research is important to answer the problems as explained above and is expected to help in improving the ability to think creatively.

Based on identifying problems and limiting problems, the problem of this researcher can be formulated as follows; 1) How to develop a monopoly learning media that can improve the ability of creative thinking and moral attitude in the content of Pancasila and Citizenship Education lessons for fourth grade students of SDN Srengseng Sawah 15 Pagi ?; 2) Is the monopoly learning media effective for improving creative thinking skills and moral attitudes in Pancasila and Citizenship Education subjects for fourth grade students of Srengseng Sawah 15 Pagi?

The objectives to be achieved in this study are to improve the creative thinking ability of the material in my Cultural Diversity Pancasila and Citizenship Education using the application of the word monopoly game media to improve creative thinking and moral attitudes of students in fourth-grade Srengseng Sawah 15 Pagi Jakarta South.

\section{Methods}

Based on the research objectives, the method used is the class action research method with reference to the Kemmis and Mc Taggart model which consists of 4 components namely planning, action, observation, and reflection. Judging from the characteristics, CAR has the characteristics of others: (1) based on the problems faced by the teacher in the learning process; (2) research as well as reflection practitioners; (3) collaboration in implementation; (4) aims to improve or improve the quality of instructional practices; (5) carried out in a series of steps with several cycles.

The core feature of the PTK method is to try out new ideas in practice as an enhancement tool and as a means of increasing knowledge about curriculum, teaching, and learning. The result is an increase in the implementation in class, better articulation and learning of the reasons why things work. Action research provides a way of working that links theory and practice to mark intact unity. PTK is shown to make changes to students themselves and changes in the situation in which research is conducted in order to achieve continuous improvement in practice. 


\section{Results}

In implementing the cycle I action the researcher obtained data about the achievement of the results of creative thinking skills in fractions as follows:

Table 1. Results of Cycle I Evaluation Analysis

\begin{tabular}{|c|c|c|c|c|}
\hline Value & Frequency & Percentage & KKM & Average \\
\hline$>>70$ & 25 & $89,29 \%$ & \multirow{2}{*}{$89,29 \%$} & 81,11 \\
\hline$<70$ & 3 & $10,71 \%$ & & \\
\hline
\end{tabular}

In cycle activities I, which was held in two meetings, the implementation of learning was not optimal, the instrument score as a result of new creative thinking skills reached $53.57 \%$ of the expected $80 \%$. While the class average reached 67.67. The results obtained for the teacher and student action monitoring instruments use the monopoly word media on the beautiful material of togetherness reaching $70 \%$ of $80 \%$

In the second cycle the students seemed more calm and understood because they already understood how to play the word monopoly, so students had not asked much anymore. Students look happy, confident, brave, and enthusiastic in answering each question monopolized by words.

The results of the creative thinking ability test in the second cycle also showed a significant increase compared to the results in cycle I. Students who scored according to the KKM in the second cycle were $89.29 \%$, for monitoring instruments the teacher's action using the fraction RME approach also experienced a significant increase of $70 \%$ to $89 \%$ and the monitoring instruments of students' actions using the RME approach to fractional material experienced a significant increase also from $56 \%$ to $89 \%$ while the required target was $80 \%$.

The table below shows the data analysis results of the evaluation study Flat on the second cycle:

Table 2. Evaluation Cycle Analysis II

\begin{tabular}{|c|c|c|c|c|}
\hline Value & Frequency & Percentage & KKM & Average \\
\hline$>>,=70$ & 25 & $89,29 \%$ & \multirow{2}{*}{$89,29 \%$} & 81,11 \\
\hline$<70$ & 3 & $10,71 \%$ & & \\
\hline
\end{tabular}

After carrying out various activities starting from the first cycle to the second cycle, the data obtained from the observations were obtained. From the results of these observations, data analysis was then carried out as a form of testing the action hypothesis using the percentage increase to see the effect of giving action through the application of word monopoly media to the creative thinking ability of togetherness in fourth grade students at Srengseng Sawah 15 Pagi South Jakarta.

Based on the analysis of data from each cycle, the results of tests of students' creative thinking skills in each cycle showed a fairly good increase. The analysis of the results of the creative thinking ability test can be seen in the table below.

In the implementation of cycle 1 and cycle 2, the researcher obtained data regarding the achievement of the results of the creative thinking ability test as follows:
Table 3. Recapitulation of Evaluation Data Analysis

\begin{tabular}{|c|c|c|c|c|c|c|}
\hline \multirow{2}{*}{ Value } & \multicolumn{2}{|c|}{$\begin{array}{c}\text { The number of } \\
\text { students }\end{array}$} & \multicolumn{2}{|c|}{ Percentage } & \multicolumn{2}{|c|}{ KKM } \\
\cline { 2 - 7 } & cycle I & cycle II & cycle I & cycle II & cycle I & cycle II \\
\hline$>=70$ & 15 & 25 & $53,57 \%$ & $89,29 \%$ & & \\
\hline$<70$ & 13 & 3 & $46,43 \%$ & $10,71 \%$ & $53,14 \%$ & $89,29 \%$ \\
\hline
\end{tabular}

The diagram below shows data on the results of evaluating the creative thinking abilities of fraction material in cycles I and II.

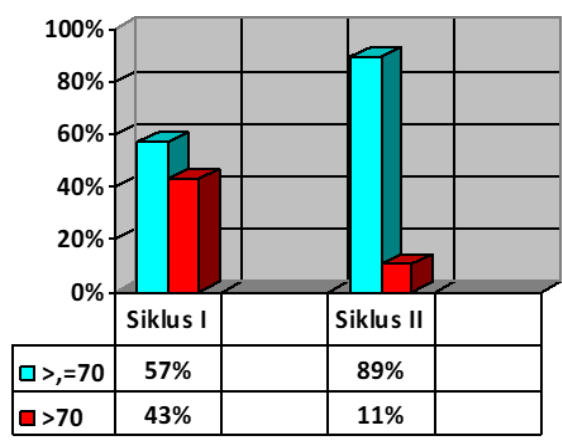

Figure 1. Result Diagram of Creative Thinking Ability Test for Fraction Materials Cycle I and II

Based on the results of data analysis, the results of tests of students' creative thinking abilities from the first cycle to the second cycle experienced a significant increase. in the first cycle the results of the students' creative thinking ability test have not reached the target set by the researcher, namely $80 \%$ of students got a score of 70 . This is because applying the monopoly media said the beauty of togetherness material was seen in the first cycle of the teacher's advantages namely; 1) the teacher has started learning by informing the monopoly word game procedure by designing media according to student characteristics and the beautiful material of togetherness; 2) the teacher helps students who have difficulty when answering questions seen the teacher interacts with students by asking what is the difficulty of the students or vice versa students ask the teacher related when expressing his opinion; 3) the teacher carefully looks at the activities carried out by each group seen during the learning process the teacher moves from one group to another; 6) the teacher provides reinforcement when students succeed in providing diverse ideas or answers in the form of appreciation in the form of words of enthusiasm to students if students answer correctly and if there are students who are wrong the teacher straightens out the answers.

While researchers using the application of the word monopoly media appear in the first cycle of teacher weakness, namely; 1) the teacher has not given freedom to students to find ideas or ideas; 2) the teacher has not maximally encouraged students to look for answers when students have difficulty answering questions; 3) students have not optimized their opinions when answering questions; 4) Students do not have courage and are still shy when answering questions; and 5) students have not maximized their time so long.

In accordance with the observer agreement, the research continued in the second cycle. The solution for researchers 
to improve in the first cycle, namely: 1) the teacher provides opportunities for students to be active in learning; 2) guiding students to find information through textbooks or other sources; 3 ) directing students to read the beautiful material of togetherness before the game starts so that they have no difficulties; 4) streamlining lesson time by determining the time of the game so that it does not take a long time; and 5) directing students to be honest, confident, and courageous in completing the questions given.

Based on the results of data analysis, the results of the students' creative thinking ability test in the second cycle were $89 \%$ so there was an increase compared to the first cycle which was only $57 \%$. In this second cycle the results of tests of students' creative thinking abilities experienced a fairly good increase. The use of the monopoly media said the material of beautiful togetherness was very helpful for students in solving questions related to the material, student interaction went well when the learning process seemed to students berantuisa, expressed opinions, expressed ideas, confidence, courage, and enthusiasm. For students who have difficulty when completing the game can read a book about the beautiful material togetherness in the textbook.

Furthermore, students have developed ideas when expressing their opinions with the ability to think creatively as seen in the results of evaluating answers so diverse. Learning activities applying the word monopoly media in cycle II are more active and enjoyable and can increase the level of students' thinking abilities. The results of data analysis on the process of testing creative thinking skills can be interpreted that the application of the word monopoly media increases the results of tests of students' creative thinking abilities in the beautiful learning of togetherness.

\section{Discussion}

The discussion of the results of this study is based on data that has been analyzed in the previous sub-chapter and findings obtained by the field. This study was also analyzed based on factors, namely the learning process applying the monopoly media to the words the beauty of togetherness by increasing students' creative thinking skills.

After analyzing the data by applying the monopoly media said the material beautiful beauty togetherness, the results of data analysis showed that there was an increase in students' creative thinking skills. The difference in improvement is based on the post-test results of cycle I and cycle II which indicate a change. After the posttest and tested data obtained the results of the study, the discussion of the results of the study was conducted.

In the implementation of learning to apply the word monopoly media begins with apperception to find out the initial knowledge of students before learning the beautiful material togetherness of class 4 semester 1 for four meetings and two meetings for evaluation. Then, communicate the learning objectives. At the core activity, carried out learning to apply the monopoly media said the beautiful material of togetherness, it seemed the enthusiasm of students when the game took place answering questions by issuing their opinions with full confidence and courage.
Similar to the development of students according to Piaget, fourth grade students are 8-10 years old, in which the development of students enters a concrete operational phase, the end period of imaginary thinking and begins to think concretely (related to the real world). So students at this time have thought something that can be accepted by reason or logic even though it is still bound by objects that are concrete so that concrete objects are needed in order to facilitate students in the learning process.

When the learning process takes place the task of the teacher is the facilitator as a guide and director. That is, if there are students who have difficulty in completing the task, the teacher directs students by giving bait questions to students so students find the next clue to complete group assignments.

Then, submitting group problems from the first to the fourth meeting, students are grouped 5-6 students in each group to play monopoly words. In submitting this group problem, students discuss with their group friends, exchange ideas, ideas or solutions. According to Torrance creativity consists of four components, namely: (1) fluency which refers to the continuity of ideas; (2) flexibility that is associated with changing ideas; (3) originality which is characterized by a unique way of thinking; (4) elaboration that refers to the ability to generalize ideas. Of these four components, novelty or originality is widely recognized and is seen as a process related to the generation of original / original ideas.

Untari \& Saputra media are used in an effort to improve the quality of the learning process. Therefore, the media must meet the general requirements, namely 1 ) the media used must be in accordance with the intended learning objectives, 2) the media used are media that can be seen or heard, 3) the learning media used can respond to learners learning, 4) learning media must be in accordance with the individual conditions of students, and 5) learning media are intermediaries in the learning process of students.

One of the media games that can lead to interesting learning activities and help the learning atmosphere to be happy, alive and relaxed. Monopoly games are expected to have the ability to involve students in teaching and learning activities actively to solve existing problems and to be competent in winning games. Media monopoly also motivates students to gain as much knowledge as possible, because students who answer many questions correctly will get toy money so that later the group will win the game.

The same thing with phase students of elementary school age (7-12 years) is marked by agile motion or motor activity. Therefore, this age is an ideal period for learning motor skills related, such as writing, drawing and coloring according to RME learning when making fraction models where students draw and write fraction symbols and color fractions. In the process of making models students have the skills to make something new to support motor development for the success of student learning.

Next, when concluding the student representatives present their work and communicate the results of the discussion's answers and other students give responses to the answers of their group friends. Some students are not afraid of being criticized, appear brave and respect the opinions of other friends when the process of delivering work in front of the class. Students equate the perception 
of the material being studied so that they can develop students' thinking skills.

Then, students' language development is seen when student representatives come forward to present the results of group discussions. There are students who express their opinions fluently. There are also those who are halting according to Abidin Syamsuddin's opinion that students who have many vocabulary means having the skills to read and communicate with others. so children are critical. Emotional development is seen every meeting of students have a feeling of pleasure, passion, enthusiasm or (curiositycuriosity) which is high in completing the game monopoly word. In social development, students are seen to discuss determining friends who are suitable and can be invited to collaborate so that they are interested in their peers' activities and their desire to be accepted as a group member is stronger.

In the learning process complete the questions and the teacher moves from one group to another to guide students who have difficulty and monitor the course of the discussion. The role of the teacher as a facilitator to guide students in solving individual problems and group problems given during the learning process. This is in accordance with the previous Chapter II, that the role of educators as facilitators, moderators or elevators.

After that, students are given individual assignments and homework (PR) to find out each student already understands the material being studied. For four learning meetings and at the end of each cycle students were given evaluation questions to determine students' thinking skills towards the RME learning approach. Data on creative thinking skills are obtained from the same posttest scores as the instrument items. The creative thinking ability test items number 10 questions which are adjusted to the indicators of learning competency achievement in the 2013 Curriculum and also indicators of creative thinking ability according to Torrance and Guilford, which have been described in Chapter II. This is based on the purpose of this study, which is to find out a description of the differences in acquisition and improvement of creative thinking skills between students by applying the word monopoly media, the indicator that researchers use is fluency and fluency, flexibility, elaboration, originality, sensitivity.

Based on the results of the descriptive analysis of overall creative thinking ability shows there is an increase in learning towards improving the ability to think creatively. This is obtained from the analysis of posttest data. Data analysis before applying the monopoly media shows results below the KKM before being given treatment with learning to apply the word monopoly media. From the results of posttest data, proving the hypothesis in the study is the application of an approach to applying the monopoly word material media to improve students' creative thinking skills.

From the pretest score data obtained it is used to see creative thinking skills that apply the word monopoly media. This is also to answer the research hypothesis stated in Chapter II. The ability to think creatively in learning to apply monopoly media scores as much as $57 \%$ of the first cycle and the second cycle to $89 \%$, then the increase can be said to be higher than the first cycle. The increase in creative thinking ability score results in the second cycle is categorized high with 25 students from 28 students who achieve a value greater and equal to 70 , while the value of less than 70 there are 3 students means that students experience an increase in the value of the test of high creative thinking skills compared to cycle I with a score greater and equal to 70 there are 16 students and less than 70 there are 12 students.

Based on the results of the above presentation and the results of the analysis of the increase in the ability to think creatively can be concluded that there is an increased ability to think creatively by applying a media monopoly said material beauty of togetherness with a higher category than conventional learning.

\section{Conclude}

Based on research carried out in the 4 th grade SDN Srengseng Sawah 15 Morning seeks to improve thinking creative students the beautiful material together with the application of the word monopoly media, and based on the results of data analysis and discussion that has been done, it can be concluded that; a) The use of the word monopoly media is able to improve creative thinking skills in fourth grade students of Srengseng Sawah 15 Elementary School in Morning 2018/2019 Academic Year, especially on the theme of the beauty of togetherness; b) By carrying out the word monopoly game which includes pictures and question questions related to the material beauty of togetherness, students are grouped 5-6 students in each group to answer each question in the monopoly of words written on each question of general and special funds and students express their opinions by giving ideas, ideas or solutions, honesty, confidence, and courage to solve questions that are in the game. Continued, students who reach theline finish means that they have finished the game, then the toy money is calculated if there is a lot of toy money then the player is declared the winner. The money obtained from the students results in their income when answering questions during the game. By applying the monopoly media, words can increase the creative thinking ability of students able to improve the quality of learning at Srengseng Sawah 15 Pagi Elementary School, especially the beautiful material of togetherness in the school year 2018/2019; c) The advantages of word monopoly media are being able to improve the ability to think creatively, able to increase student activity, speaking skills when expressing their opinions, communicating diverse answers, being able to issue ideas or solutions in solving problems; d) The weakness of the word monopoly media is that it takes a long time to play

\section{References}

[1] Direktorat Jendral Pendidikan Dasar Dan Menengah Kementerian Pendidikan Dan Kebudayaan., Peraturan Menteri Pendidikan Nasional Republik Indonesia Tentang Standar Kurikulum 2013. Jakarta: Direktorat Jendral Pendidikan Dasar Dan Menengah Kementerian Pendidikan Dan Kebudayaan, 2013.

[2] K. Anna Perry., "Efficacy of Teaching Creative Thinking Skills: A Comparison of Multiple Creativity Assessments," J. Think. Ski. Creat., vol. 24, pp. 118-126, 2017.

[3] Suwasto, "Peningkatan Hasil Belajar PKn Materi Konsep Nilainilai Pancasila sebagai Dasar Negara dan Ideologi melalui Metode Diskusi dan Resitasi,” J. Din., p. 2, 2002. 
[4] Ali Mahmdi, "Mengukur Kemampuan Berpikir Kreatif Matematis," Konf. Nas. Mat. XV, p. 1, 2010.

[5] T. B. Sanit Srikoon, "Effect of 5P model on academic achievement, creative thinking, and research characteristics," Kasetsart J. Soc. Sci., vol. 39, no. 3, pp. 488-495, 2018.

[6] Nadezhda Yachina, "Of Spiritual And Moral Formation Of Personality,” J. Procedia - Soc. Behav. Sci., vol. 197, pp. 1575-1579, 2015.

[7] Radka Bužgová dan Lucie Sikorová, "Moral judgment competence of nursing students in the Czech Republic,” J. Nurse Educ. Today, vol. 33, pp. 1201-1206, 2012.

[8] Fitriyawany, "Penggunaan Media Permainan Monopoli Melalui
Pembelajaran Kooperatif Pada Mahasiswa Fisika Fakultas Tarbiyahdengan Konsep Tata Surya,” J. Ilm. Didakt., vol. 13, pp. 223-229, 2013.

[9] Samrin, "Pendidikan Karakter (Sebuah Pendekatan Nilai)," J. Al-Ta'dib, vol. 9, no. 1, p. 133, 2016.

[10] O'Halloran, "Designing a Game Based on Monopoly as a Learning Tool for Lodging Development,” J. Hosp. Tour. Educ., vol. 22, no. 3, p. 37, 2017.

[11] Utomo Damanjaya, Media Pembelajaran Aktif. Bandung: Nuansa Cendekia, 2010.

[12] A. Sudono, Sumber Belajar Dan Alat Permainan;Untuk Pendidikan Anak Usia Dini. Jakarta: PT Grasindo, 2000. 